\title{
The Gender Selectivities of the State
}

\author{
A Critical Realist Analysis
}

\begin{abstract}
.
This article develops a critical realist, strategic-relational analysis of the gendering of the state. It draws freely from feminist theorists, recent work on masculinity, and some of the insights of 'queer theory'. ${ }^{1}$ My aim is to show the contingently necessary nature of the gender biases in the state's institutional architecture and operation and show how these can be illuminated through a critical realist, strategic-relational perspective. The article has four main parts. These deal with (a) critical realism and the strategic-relational approach (hereafter SRA); (b) its implications for analyzing gender selectivities;

(c) the gender selectivities of advanced capitalist democratic states; and

(d) some implications of strategic selectivity for feminist action.
\end{abstract}

\section{Key words:}

Critical realism; strategic-relational approach; strategic selectivity; state theory; gender; patriarchy

\section{Critical Realism and the Strategic-Relational Approach}

My introductory remarks on critical realism (CR) are brief because most readers of this journal will already be familiar with its basic features. Moreover, however strong the arguments in favour of critical realism in general and their resulting exclusion of alternative ontologies, epistemologies, and methodologies, they cannot justify any particular version of critical realism and show its superiority to other versions. Yet this article develops just such a particular version to study the state's gender specificities. It does not aim to present the definitive account but to open a space for critical realist debate about the nature and effectivity of the state's gender biases..

Ontologically, critical realism distinguishes the real, the actual, and the empirical and explores their internally (or naturally) necessary and/or their externally contingent relations. The actualization of naturally necessary powers is not guaranteed. Indeed, we can go further and argue that the tendencies of social systems, structures, and other social relations are always 'doubly tendential'. For these tendencies exist only to the extent that the social relations that generate them are themselves reproduced; if these social relations are modified or eliminated, then their naturally necessary (or intrinsic) properties will be modified or eliminated too. This also has implications for the relation between structure and agency and, a fortiori, for the constraining/ enabling

\footnotetext{
${ }^{1}$ I have benefitted from discussions with Anne-Marie Fortier, Andrea Maihofer, Andrew Sayer, Mimi Sheller, Ngai-Ling Sum, and Sylvia Walby and comments from Mervyn Hartwig and two anonymous referees. The usual disclaimers apply.
} 
power of structures and for the reproductive/transformative power of agency. In addition, methodologically, as is well known, critical realists reject the search for constant conjunctions or other empirical regularities as an adequate basis for generating scientific knowledge. Instead they engage in empirically- and theoretically-informed retroduction to identify causal powers, liabilities, and other real mechanisms and the necessary and sufficient conditions for their actualization. ${ }^{2}$ Thus the emphasis is on producing critically realist explanatory critiques that could inform an emancipatory politics. ${ }^{3}$ This is a continuing, fallible, corrigible, and openended process. Moreover, an explanation is only ever adequate relative to the definition of the explanandum and no explanation is ever complete as long as the explanandum can be made more concrete and/or complex. ${ }^{4}$

The strategic-relational approach (SRA) offers a particular critical realist account of the dialectic of structure and agency that is consistent with these ontological and methodological assumptions. ${ }^{5}$ It examines structure in relation to action, action in relation to structure, rather than bracketing one or the other. Thus structures are treated analytically as strategic in their form, content, and operation; and actions are treated analytically as structured, more or less context-sensitive, and structuring. This involves examining how a given structure may privilege some actors, some identities, some strategies, some spatial and temporal horizons, and some actions over others; and the ways, if any, in which actors (individual and/or collective) take account of this differential privileging by engaging in 'strategic-context' analysis when choosing a course of action. ${ }^{6}$ This privileging is doubly tendential in both respects and must be examined in terms of the contingent relationship between the real, the actual, and the empirical. Rather than bracketing structural and strategic perspectives, combining them in this way means studying structures in terms of their structurally-inscribed strategic selectivities and studying actions in terms of (differentially reflexive) structurally-oriented strategic calculation. It also means introducing a distinctive evolutionary perspective into critical realism and strategic-relational analysis that explores how the generic mechanisms of selection, variation, and retention operate in specific conditions to produce relatively coherent and durable structures and

\footnotetext{
2 Cf. Adams: 'Contra Pringle and Watson, and other postmodern analysts, a state or interstate system should be approached with methodological tools adequate to its evolving character as a variably coherent, variably contradictory formation, not simply "as a diverse set of discursive arenas which play a crucial role in organizing relations of power"'. See Julia Adams, 'Feminist theory as fifth columnist or discursive vanguard? Some contested uses of gender analysis in historical sociology', Social Politics vol. 5, no. 1, 1998, 1-16. Adams is referring to Rosemary Pringle and Sophie Watson, '"Women's Interests" and the post-structuralist state'. In Michèle Barrett and Anne Phillips, eds, Destabilizing Theory. Contemporary Feminist Debates (Cambridge: Polity, 1992), pp. 53-73, at p. 70.

${ }^{3}$ Caroline New, 'Feminism, critical realism and the linguistic turn'. In Justin Cruickshank, ed., Critical Realism: the Difference it Makes (London: Routledge, 2003), pp. 57-74.

${ }^{4}$ Critical realism also rests on key epistemological assumptions; but these are not directly relevant to my argument in this article. See Roy Bhaskar, The Possibility ofNaturalism (Hemel Hempstead: Harvester Wheatsheaf, 1989, second edition); Andrew Sayer, Realism and Social Science (London: Sage, 2000).

5 For a more extended account of the strategic-relational approach, see Bob Jessop, 'Institutional (re)turns and the strategic-relational approach', Environment and Planning A vol. 33, no. 7, 2001, pp. 1213-37.

${ }^{6}$ On strategic context analysis, see Rob Stones, 'Strategic context analysis', Sociology vol. 25, no. 4, 1991, pp. 673-96.
} 
strategies. ${ }^{7}$ Moreover, given that the evolution and operation of such selectivities can be analyzed at different levels of abstraction-simplicity or concreteness-complexity, the sorts of explanations offered will legitimately vary in their sophistication provided that they remain commensurable and consistent as one moves to increasingly finedetailed analyses.

The SRA also implies that opportunities for reorganizing specific structures and the scope for strategic reorientation are themselves subject to structurally-inscribed strategic selectivity and so have path-dependent as well as path-shaping aspects. For example, it may be necessary to pursue strategies over several spatio-temporal horizons of action and to mobilize different sets of social forces in different contexts to modify or eliminate the constraints and opportunities linked to particular structures. Likewise, the recursive selection of strategies and tactics depends on individual, collective, or organizational learning capacities and on the 'experiences' resulting from the pursuit of different strategies and tactics in different conjunctures. Insofar as reflexively reorganized structures and recursively selected strategies and tactics coevolve over time to produce a relatively stable order out of a potentially unstructured complexity, we can talk of the structured coherence of this co-evolving, selforganizing order. This involves a structurally-inscribed strategic selectivity that differentially rewards actions compatible with the recursive reproduction of the structure(s) in question. This emergent structural and strategic coherence can be illustrated from periods of relative stability in capitalism and from the durability of patriarchal structures. Nonetheless, from the viewpoint of a critical realist SRA, the emergence and reproduction of these forms of coherence are always contingent. This is the case for at least three reasons. First, precisely because the reproduction of structures is only ever tendential, so too are their strategic selectivities. Second, because structures are strategically selective rather than absolutely constraining, there is always scope for actions to overflow or circumvent structural constraints. And, third, because subjects are never unitary, never fully aware of the conditions of strategic action, never fully equipped to realize their preferred strategies, and always face possible opposition from actors pursuing other strategies or tactics, failure is an ever-present possibility.

\section{Analyzing Gender Selectivities}

The SRA is premised on the contingent, relational nature of all identities, interests, strategies, and spatio-temporal horizons; and it allows for, without taking for granted, their reflexive transformation. These premises problematize the gender selectivities of any system, institution, or social practices by highlighting the contingency, historicity, and variety of gender identities and interests that might serve as reference points for assessing these selectivities. As Joan Scott notes, one cannot just assume 'the abiding

\footnotetext{
7 On the evolutionary aspect of a critical realist SRA, see Bob Jessop, 'Critical semiotic analysis and cultural political economy’, Critical Discourse Studies vol. 1, no. 2, 2004 (in press).
} 
existence of a homogeneous collectivity called "women" upon which measurable experiences are visited'. ${ }^{\text {The }}$ These premises also indicate a broad range of possible explanatory factors. For an adequate strategic-relational analysis of gender relations would refer to the constitution of competing, inconsistent, and even openly contradictory identities for both males and females, their grounding in discourses and fantasies about masculinity and/or femininity, ${ }^{9}$ their explicit and/or implicit embedding in different institutions and material practices, ${ }^{10}$ and their physico-cultural materialization in human bodies. It is particularly important how specific constructions of masculinity and femininity, their associated gender identities, interests, roles, and bodily forms come to be privileged in the state's own discourses, institutions, and material practices.

Such an approach is very useful in contesting the recurrent tendency to 'naturalize' gender and gender relations rather than to analyze them as social and/or discursive constructs. This tendency is not confined to 'malestream' analyses: it also occurs in much feminist work, especially in first- and second-wave feminisms. ${ }^{11}$ Several theoretical and political strategies have been suggested to counter this. Two are worth noting here. First, according to 'queer theory', sexual, or gender identities (and, by analogy, all other identities) tend to be ambivalent and unstable and sexual orientations and practices are 'polymorphous'. ${ }^{12}$ Second, whether or not they share this rejection of 'heteronormative' analyses, many other approaches emphasize the differential articulation (or intersection) of gender with class, ethnicity, 'race', disability, and so on (see below). Such radical deconstructions of gender and sexuality reveal the complex overdetermination of the state's gender selectivities, their inherently relational - including spatio-temporal - nature, and their variable impact on political strategies and practice. This approach denies that the state is a simple

\footnotetext{
${ }^{8}$ Joan W Scott, 'Some reflections on gender and politics', in Myra Marx Ferree, Judith Lorber, and Beth B. Hess, eds., Revisioning Gender (London: Sage, 1999), p.76. See also Andrea Maihofer, Geschlecht als Existenzweise (Frankfurt: Ulrike Helmer Verlag, 1995), pp. 21-22, 69-108.

${ }^{9}$ Issues about the state's selectivity also arise regarding different biological sexes (including 'awkward' cases, whether due to genetic endowment or surgical intervention), sexual identities (with growing recognition of transgender identities), and sexual preferences (through the rise of the gay, lesbian, and bisexual movements and through debate over issues such as bestiality, incest, paedophilia, pornography, and sado-masochism).

${ }^{10}$ In distinguishing discourses, institutions, and material practices, I am not denying the materiality of discourses nor suggesting that institutions or material practices are non-discursive. But not all discourses are translated into institutions and material practices with emergent properties and effects that are irreducible to the content of these discourses - some discourses simply exist and circulate as discourses and have effects only on other discourses

${ }^{11}$ For useful critiques, see Nancy Fraser, 'Equality, difference and democracy', in Jean Dodi, ed., Feminism and the New Democracy: Re-Siting the Political (London: Sage, 1997), pp. 98-109; Scott, 'Reflections'

${ }^{12}$ On the state, see Lisa Duggan, 'Queering the state', Social Text no. 39, 1994, pp. 1-14; for a critique of some political implications of queer theory, see Suzanna D. Walters, 'From here to queer: radical feminism, postmodernism, and the lesbian menace (Or, why can't a woman be more like a fag?)', Signs vol. 21, no. 4, 1996, pp. 830-69; Michelle Renée Matisons, 'The new feminist philosophy of the body', European Journal of Women's Studies vol. 5, no. 1, 1998, pp. 9-34; Adam Isaiah Green, 'Gay but not queer: toward a post-queer study of sexuality', Theory and Society vol. 31, no. 4, 2002, pp. $521-45$.
} 
expression of patriarchal domination and even questions the utility of 'patriarchy' as an analytical category. It takes us beyond the recognition that multiple structures of patriarchy exist, they can be transformed, and changes within and across interlocking forms of patriarchy are contingent and overdetermined. It suggests that the significance of such patriarchal structures and their articulation to produce specific 'gender regimes' can be adequately grasped only through a further round of deconstruction inspired by third-wave feminism, 'queer theory', and similar modes of analysis of other sites and forms of domination. For this will make it easier to discover which are the naturally necessary aspects, if any, of the state as a patriarchal institution; which are contingent structural features of the state in a patriarchal society; and which are random and hence more readily modifiable. ${ }^{13}$

These assertions can be developed by critiquing MacInnes's account of the 'postpatriarchal' modern period. ${ }^{14}$ MacInnes sees the latter as transitional - separating a (moribund) traditional patriarchal and a (potential) future non-patriarchal era. It therefore involves various structural and discursive contradictions insofar as important institutional and ideological legacies dating from the era of open private and public patriarchal domination are now threatened and, despite occasional significant temporary reversals, increasingly undermined by the more universalist logics of the market and liberal democracy. This erosion by possessive individualism is uneven, still incomplete, and far from an unqualified good. ${ }^{15}$ MacInnes is well aware that a sexual division of labour survives in which 'males and females routinely perform different activities or occupy different social roles, receive different material rewards and have access to contrasting amounts of power and status because of their sex'. ${ }^{16}$ But he denies that these enduring inequalities can be explained in terms of (naturalized) gender differences because, for him, these differences are themselves 'the ideological result of a material struggle over the sexual division of labour'. ${ }^{17} \mathrm{He}$ argues that this naturalization of gender differences reflects social constructions of masculinity and femininity based on alleged differences between males and females. ${ }^{18}$ Such fetishism is in turn an unstable expression of efforts to re-assert the legitimacy of the sexual division of labour after the 'naturalness' of patriarchy had been challenged by commitments to formal ${ }^{19}$ equality in market relations and liberal

\footnotetext{
${ }^{13}$ Cf. New, 'Feminism', p. 57.

${ }^{14}$ John MacInnes, The End of Masculinity: The Confusion of Sexual Genesis and Sexual Difference in Modern Society (Milton Keynes: Open University Press, 1998).

${ }^{15}$ Thus neo-liberal theorists such as Hayek and Friedmann believe that, because gender discrimination blocks the efficient allocation of resources to maximize profits, it will disappear as rational market calculation spreads.

${ }^{16}$ MacInnes, End of Masculinity, p. 1.

${ }^{17}$ MacInnes, End of Masculinity, p. 2. For a more extreme, constructivist (or performativist) view, that sex and gender are both social constructs, see Judith Butler, Bodies that Matter (London: Routledge, 1993); and, for a sympathetic critique of this position, see Andrea Trumann, Feministische Theorie. Frauenbewegung und weibliche Subjektbildung im Spätkapitalismus (Stuttgart: Schmetterling Verlag, 2002), pp. 148-168.

${ }^{18}$ See Jeffrey Weeks, Sexuality. (Chichester: Ellis Horwood, 1986); Scott, 'Reflections'.

19 Formal equality in market relations and liberal democratic politics is quite compatible with substantive inequalities - whether generated by the logic of capitalist relations of production, the contingent articulation between exchange relations and pre-existing substantive inequalities (as exemplified in segmented labour or product markets), the contradictions between the state's democratic public form and its substantive dependence for resources (and, often, legitimacy) on economic performance, and the contradictions between the formal equality of citizens and unequal access to public will formation, policy making, and policy implementation.
} 
democratic politics. Thus one can expect there to be significant structural and discursive contradictions between the gender selectivities and operational logics of the various functional orders of modern society - the capitalist economy, the formally democratic state, the overall family system, and so forth. For each of these embeds the historical contradiction between the substantive institutional and discursive legacies of patriarchy and the - at least - formally gender-neutral potential of modern institutions. MacInnes concludes that there is 'a real contradiction in modernity at both the ideological and material levels between the legacy of patriarchy and its historical defeat - between the sexual contract and the social contract' ${ }^{20}$ Nonetheless, third-wave feminism and queer theory can be deployed to suggest three criticisms of MacInnes's account. First, his distinction between patriarchal, transitional, and postpatriarchal periods inclines to a progressive, liberal, and possibly teleological, reading of history. Thus it tends to ignore the scope for transformations in patriarchy, e.g., from private patriarchy to public patriarchy, as well as the scope for reversals. It tends to subscribe to the individualist, universalist values of the capitalist market, liberal democracy, etc., as well as the various discursive, institutional, and systemic boundaries and/or exclusion-inclusion mechanisms associated therewith. And it tends to imply that the erosion of patriarchy would be accomplished when these individualist, universalist values have been achieved - even though there are rich feminist (and, indeed, other radical) critiques of the biases in such apparently 'genderblind' discourses and institutions. All of this leaves little space for considering the arguments and strategies of third-wave feminism and 'queer theory', which criticize and oppose the sort of liberal strategies implicit in MacInnes's analysis. Second, perhaps because it is so strongly grounded in a critique of western political theory and radical first-wave feminism, his arguments tend to be Eurocentric or, at least, to be grounded in the Enlightenment tradition. In this sense they ignore the problems posed by imperialism, colonialism, and post-colonialism and the 'peculiarities' (from a Eurocentric viewpoint) of patriarchy outside the European and North American heartlands. Thus his analysis runs the risk of reproducing an implicit modernization thesis in which all societies face a putative post-patriarchal future like that developing in the allegedly most progressive western societies. And, third, MacInnes's analysis focuses more or less exclusively on the antagonisms rooted in the 'sex-gender' nexus and so ignores the lessons of third-wave feminist analyses of the intersection of gender, class, 'race', ethnicity, nation, and other identities. ${ }^{21}$ Taking account of these issues poses quite different problems about identities, interests, alliances, political strategies and tactics, spatial and temporal horizons of action, respect for boundaries and borders, and so forth.

This argument is reinforced when we consider the lifeworld, which I define here as a heterogeneous social space constituted by identities, values, discourses, and practices that are largely located beyond the system world. These identities, values, discourses, and practices can provide significant material-discursive bases for identity politics and

\footnotetext{
${ }^{20}$ MacInnes, End of Masculinity, p. 131.

${ }^{21}$ New argues that critical realism can assist in the discovery of these interactions, 'Feminism', p. 71. They are at the centre of Patricia S. Mann's theory of post-modern, post-feminist theory of the selfconstruction of political identity and political agency. See her Micro-Politics: Agency in a Postfeminist Era (Minneapolis: University of Minnesota Press, 1994).
} 
become the basis for what Nancy Fraser terms the politics of misrecognition, i.e., 'institutionalized patterns of interpretation and evaluation that constitute one as comparatively unworthy of respect or esteem'. ${ }^{22}$ Gender relations are just one, albeit a very important, locus of such misrecognition (or domination) within the lifeworld: others include (likewise socially constructed) social relations such as ethnicity, 'race', nations, generation, and lifestyle. Hence the lifeworld cannot be presented, as in certain idealized formulations, as the (potential) sphere of freedom in contrast to the system world as the (necessary) sphere of domination. In their respective and often overlapping pluralities, both worlds are sites of struggle - sites that may also come to be structurally and/or strategically linked in relatively durable, strategically-selective patterns. They also form strategic terrains for attempts to resolve the general contradiction between the legacies of pre-modern patriarchy and the logics of modern functional systems as these are overdetermined in particular social formations; and for attempts to contest prevailing discourses of masculinity and femininity as these are expressed in and across these two disparate and complex worlds. The temporary, partial, and unstable compromises that tend to emerge in the various fields of gender struggle will be codified in different discourses, institutions, and practices. At least some fields will institutionalize the prevailing hegemonic or dominant images of masculinity and femininity - even as others afford bases of strategic resistance or tactical opposition. These ideas are inconsistent with two basic assumptions once implicit in much feminist argument: first, that there is a single, well-defined, and strongly institutionalized form of patriarchy with its own distinctive logic that is expressed in different fields; and, second, that there is a sharp division, if not antagonism, between all men and all women. Most feminists now recognize that there are different forms of patriarchy; ${ }^{23}$ that there is wide variation in both masculinities and femininities and therefore in possible 'gender regimes'; ${ }^{24}$ and that gender regimes are always and everywhere overdetermined by at least class, nation, ethnicity, and 'race'. ${ }^{25}$ The debate has moved well beyond claims that the state is the "patriarch general', ${ }^{26}$ or its policies toward women could be derived from the logic(s) of production and/or reproduction in capitalist societies. ${ }^{27}$ Indeed, there is a growing debate over the continued validity of the category of gender. ${ }^{28}$ The current agenda

\footnotetext{
22 Nancy Fraser, 'Heterosexism, misrecognition and capitalism: a response to Judith Butler', New Left Review, no. 228, 1998, pp. 140-149, at p. 141 (italics in original).

${ }^{23}$ See, for example, Sylvia Walby, Theorizing Patriarchy (Oxford: Blackwell, 1990).

${ }^{24}$ For example: Robert W. Connell, Gender and Power: Society, the Person and Sexual Politics (Cambridge: Polity, 1990); Robert W. Connell, Masculinities (Cambridge: Polity, 1995).

Maria Mies, Patriarchy and Accumulation on a World Scale (London: Pluto, 1986

${ }^{25}$ For example: Jane Jenson, 'Gender and reproduction: or babies and the state', Studies in Political Economy no. 20, 1986, pp. 9-46; Helen Callaway, Gender, Culture and Empire: European Women in Colonial Nigeria (Basingstoke: Macmillan, 1987); Chandra T. Mohanty, 'Under western eyes: feminist scholarship and colonial discourses', in Chandra T. Mohanty, Ann Russo, and Lourdes Torres, eds., Third World Women and the Politics of Feminism (Bloomington: Indiana University Press, 1991), pp. 1-47; Kathleen Canning, 'Gender and the politics of class formation: rethinking German labor history', American Historical Review vol. 2, 1992, pp. 736-68; Eileen Boris, 'The racialized, gendered state: constructions of citizenship in the United States', Social Politics vol. 2, no. 2, pp. 16-80; Nira YuvalDavis, Gender and Nation (London: Sage, 1996); Patricia Hill Collins, 'It's all in the family: intersections of gender, race, and nation', Hypatia vol.13, no. 3, 1998, pp. 62-82; Fraser, 'Equality'.

${ }^{26}$ Maria Mies, Patriarchy and Accumulation on a World Scale (London: Pluto, 1986).

${ }^{27}$ Michèle Barrett and Mary McIntosh, The Anti-Social Family (London. Verso, 1985).

${ }^{28}$ Susan Bordo, 'Feminism, postmodernism, and gender-scepticism'. In Linda J. Nicholson, ed., Feminism/Postmodernism (London: Routledge, 1990), pp. 133-156; and Maihofer, Geschlecht als Existenzweise, passim.
} 
concerns how best to analyze the contingent co-evolution, structural coupling, and discursive articulation of various state structures, discourses, and practices with diverse patriarchal structures, discourses, and practices - whilst paying due regard to the structural contradictions, strategic dilemmas, and discursive paradoxes that are typically associated with these processes. This suggests three closely interrelated sets of questions.

First, to what extent do the particular operational codes and programmes of various orders in the 'system world' consistently tend to select and thereby reinforce some gender-coded differences and/or some sexual orientations and not others? Even if the general codes of functional systems are gender-neutral, particular programmes applied by specific organizations and actors may well be gender-biased. For example, how far, in what respects, and under what conditions would 'particular capitals' or, indeed, 'capital in general' enhance profits by exploiting gender differences? Moreover, given that different capitals may have opposing interests in this regard, how easy is it to manage the resulting contradictions, dilemmas, and paradoxes? Making due allowances for different operational codes and programmes, similar questions can be posed about other functional systems, such as politics, law, education, art, science, war, religion, or medicine. Second, how far, in what respects, and under what conditions, do hegemonic and/or dominant concepts of masculinity and femininity (or maleness and femaleness) serve to organize men's and women's differential participation in the system world? While the first set of questions concerns the general interest, if any, of functional systems in gender discrimination, this set inquires into possible discursive, institutional, and material obstacles to 'gender blindness' where such neutrality might otherwise be favoured by the general code or specific programmes of a given functional system. And, third, how far, in what respects, and under what conditions, do concepts of masculinity and femininity (or maleness and femaleness) organize social identities, interests, values, discourses, and practices that are external to, or cut across, the system world. Concepts of masculinity and femininity as well as of maleness and femaleness should be studied in terms of their discursive constitution, institutional embeddednesss, and personal embodiment. Masculine and feminine (or male and female) stereotypes may be more or less sharply differentiated in terms of their substantive and/or evaluative content in regard to systems and the 'lifeworld'. They may also be more or less tightly (or loosely) coupled to a wider (or narrower) range of activities in both regards. In general, the less substantive and evaluative differentiation there is between the concepts of masculinity-femininity and/or maleness-femaleness, the less tightly coupled these twin concepts are, and the narrower is the scope of their institutionally and discursively constituted relevance, the less likely it is that gender selectivities will be well-established. These three sets of questions provide a useful way to analyze and explain the gender selectivities of the state and the overall political system, to indicate that there are various forms of gender regime and gender selectivity, and to explore their markedly differential effects on different social categories or social forces according to their identities, interests, and strategic orientations to malenessfemaleness, masculinity-femininity, or sexual orientation. The specific configuration 
of selectivities associated with a specific gender regime in particular conjunctures results from a complex set of path-dependent interactions. Among the factors involved are the operational logics of modern functional systems, the legacies of premodern patriarchy, current modes of domination in the lifeworld and the struggles around them, attempts to colonize the lifeworld by specific systems and resistance thereto, and the hegemonic struggles to secure an overall balance between system integration and social cohesion. If one accepts this critical realist, strategic-relational approach, there is no transhistorical inevitability about patriarchy. It is not a monolithic and/or inertial structure of domination but involves polymorphous and contingent gender regimes. This approach also suggests that any residual impression that patriarchy (whether seen as monolithic or polymorphous) is necessarily inscribed into capitalism and/or the state probably results from the structural coupling and contingent co-evolution of different systems (especially the market economy and the liberal democratic state) with modes of domination rooted in the lifeworld. Such contingent necessities do not mean that gender domination is less real because it is far from transhistorical. But social forces might be better placed to challenge, modify, and eliminate gender domination if they recognize its contingency and search for its vulnerabilities as well as its strengths.

\section{A Critical Realist, Strategic-Relational Approach to the State}

For a critical realist, strategic-relational approach to the state, the exercise and effectivity of state power are the materially and discursively mediated condensations of the changing balance of forces in political struggle. ${ }^{29}$ State power results from a continuing interaction between the structurally-inscribed strategic selectivities of the state as an institutional ensemble and the changing balance of forces operating within, and at a distance from, the state and, perhaps, also trying to transform it. ${ }^{30}$ More specifically, in analyzing the strategic selectivities of the state as a social relation, its bias as a strategic site of political action must be connected to specific strategies pursued by specific forces (or sets of such forces) with specific identities in order to advance specific interests over specific spatial and temporal horizons relative to specific other forces, each advancing their own interests through their own strategies over their own spatial and temporal horizons. Particular forms of state and particular state capacities privilege the access of some forces over others, some strategies over others, some interests over others, some spatial and temporal horizons of action over others, and some coalition possibilities over others. How far and in what ways the powers (and any associated liabilities or vulnerabilities) of given state forms or political regimes are actualized will depend on the action, reaction, and interaction of specific social forces located both within and beyond this complex ensemble. For the state does not exercise power: its powers (in the plural) are activated through specific sets of politicians and state officials located in specific parts and levels of the state system. In doing so, they may well take account of the prevailing and, perhaps, future balance of forces in and beyond the domestic state and/or its external borders.

\footnotetext{
${ }^{29}$ This paragraph draws heavily on Bob Jessop, State Theory (Cambridge: Polity, 1990), pp. 252-270; and idem, 'Critical realism and hegemony. Hic Rhoda, hic saltus', Journal of Critical Realism vol. 1, no. 2, 2003, pp. 183-194.

${ }^{30}$ Compare Nicos Poulantzas's remarks on the state as a social relation in State, Power, Socialism (London: Verso, 1978).
} 
Moreover, as usual, unacknowledged conditions influence the success or failure of their actions and there are always unanticipated consequences. This suggests that a change in the self-identity of political forces, the pursuit of different interests, the development of different strategies, the adoption of different spatial and/or temporal horizons of action, or the building of different blocs, strategic alliances, or temporary coalitions could well lead to different outcomes, making it easier or harder to achieve specific objectives in and through a given type of state, a given state form, or a given form of regime. It also suggests that reorganizing the state - its modes of representation, internal articulation, modes of intervention, social bases, the currently dominant state project or mode of political legitimation, or, where relevant, the state's hegemonic project for the wider society - will change its strategic selectivities. All of these claims are fully consistent with the general arguments of critical realism and the particular claims of the strategic-relational approach noted above and are also broadly consistent with the transformational model of social action initially proposed by Roy Bhaskar. ${ }^{31}$ But they have been re-specified to take account of the distinctive features of the state as an institutional ensemble and of state power as a social relation especially to highlight the doubly tendential nature of strategic selectivities as causal mechanisms - and they will be further re-specified as I develop a progressively more concrete-complex (but still incomplete) analysis of the patriarchal capitalist state below.

\section{The State's Gender Selectivities}

There can be no final judgment about the state's gender selectivities. First, there are many forms of state and political regime with different structures of political opportunity. Second, there are different forms of gender-conditioned, genderconscious, and gender-relevant mobilization, different identities and interests around which such mobilization occurs, different standpoints and horizons of action with which it is associated, and different strategies and tactics that are pursued. And, third, since gender selectivities result from structures and strategies, any blanket claim risks being tautological, trivial, or overly abstract. Nonetheless, a critical realist, strategicrelational approach to the state's gender selectivities should aim to identify the mechanisms and practices through which the state transforms, maintains, and reproduces institutionally and discursively materialized, asymmetrically structured power relations between men and women as the bearers of diverse gender identities and interests. Thus I will now seek to establish certain broad principles on the basis of first- and second-wave feminist perspectives that consider some key institutional features of the modern state and its environing political system and then qualify or extend some arguments on the basis of third-wave feminism. ${ }^{32}$

\section{Historical and formal constitution of the modern state}

\footnotetext{
${ }^{31}$ On some differences between Bhaskar's TMSA and the SRA, see Bob Jessop, 'Critical realism and the strategic relational approach'. New Formations 2004 (forthcoming).

${ }^{32}$ For an earlier strategic-relational deconstruction of the supposed gender blindness of the state, see Birgit Sauer, 'Die Magd der Industriegesellschaft: Anmerkungen zur Geschlechtsblindheit von Staatsund Institutionentheorien', in Brigitte Kerchner and Gabriele Wilde, eds., Staat und Privatheit (Opladen, 1987), pp. 29-54; and for an analogous 'queer-theoretical' analysis of the local state, see Davina Cooper, Sexing the City: Lesbian and Gay Politics within the Activist State (London: Rivers Oram Press, 1994).
} 
We can refine MacInnes's analysis by distinguishing the historical and formal constitution of the modern state. Whereas historical constitution concerns the complex, path-dependent, historical emergence of a modern state with a legitimate monopoly of organized coercion in a given territory, formal constitution refers to the state's acquisition of a formal structure (set of forms) adequate to rational capitalism. ${ }^{33}$ This distinction has two key implications. On the one hand, modern states were not constructed on a political tabula rasa but on the historically variable foundations of past social forms and discourses. This helps to explain the survival of pre-modern patriarchal features that contradict the emergent, formally rational form of the modern state. On the other hand, since formal constitution does (and must) develop in an inherited patriarchal context, the modern state also displays a substantive, path-dependent structured coherence with patriarchy. This involves: (a) the recursive selection and reinforcement of 'appropriate' political practices that tend to reproduce the disempowerment of women in a de facto patriarchal state; and (b) the self-limiting nature of attempts to change this state form such that its gender selectivities are maintained. An exemplary historical study of such structural coupling (although not presented as such) is Vogel's account of how the contradiction between private possessive individualism and patriarchal state control over marriage was entrenched in the 1804 French Code civil. ${ }^{34}$ An equally exemplary contemporary analysis is Ray's material-discursive and relational analysis of women's movements in Calcutta and Bombay - cities characterised by very different political 'fields'. Whereas Calcutta has a hegemonically-organized field with a homogeneous political culture and a concentrated distribution of power, Bombay has a fragmented field with a heterogeneous political culture and dispersed distribution of power. This has major consequences for the forms, social bases, aims, relative autonomy or subalternity, dynamics, and effectiveness of women's movements in the two cities. ${ }^{35}$

\section{Formal features of the modern state}

I now explore three key features of the formally rational modern state. These are its constitutionalized monopoly of organized violence vis-à-vis the economy and civil society and its territorialized sovereignty vis-à-vis other states; its nature as a state based on the rule of law, with its clear demarcation between public and private; and the nature of statecraft, statistics, and other aspects of official discourse as formsof power/knowledge. Each of these features is associated with specific biases in the overall operation of the modern state and, as biases rather than structural guarantees, they operate in a tendential (and, indeed, doubly tendential) manner. A critical realist, strategic-relational approach is therefore particularly suited to revealing how they operate and are reproduced.

The modern state's Gewaltmonopol has two interesting features: first, direct coercion is excluded from the organization of production for the market; and, second, from a police-military rather than economic perspective, its monopoly of organized coercion

\footnotetext{
${ }^{33}$ See Bob Jessop, The Capitalist State (Oxford: Martin Robertson, 1982); Max Weber, Economy and Society (Berkeley: University of California Press, 1968).

${ }^{34}$ Ursula Vogel, 'The state and the making of gender'. In Vicky Randall and Georgina Waylen, eds., Gender, Politics and the State (London: Sage, 1999), pp. 29-45.

${ }^{35}$ Raka Ray, Fields of Protest. Women's Movements in India (Minneapolis, University of Minnesota Press, 1999).
} 
promotes the pacification of civil society and allows the centralization of military force to defend the state's territorial integrity. These features are often considered hallmarks of modernity. However, although formally 'gender-neutral', they are quite consistent with continuing patriarchal practices. The absence of direct coercion from production by no means rules out gendered divisions in the labour process. It is also quite consistent with state indifference - official or unofficial - to abuse and violence in the 'private' sphere directed against women and children. ${ }^{36}$ Nor does the pacification of civil society exclude other forms of domination. Indeed continuing gender bias has provoked attempts to politicize the personal, to open public space to women's interests, and to establish children's rights. Likewise the state's control of police-military functions does not as such prevent hegemonic masculinity influencing their exercise. This is reflected in the historical link between citizenship and military service obligations, in institutionalized gender and 'heteronormative' bias(es) in the organization and operations of the police and military, in state- or military-sponsored prostitution, and, too often, in practices such as martial rape or torture. Indeed, insofar as police-military functions are still central to the state's overall operation, they may spread masculinist or patriarchal influence throughout the state system. ${ }^{37}$

Territorialized sovereignty is another important feature of the modern state and is the historical basis of inter-state relations, military-police organization, nation-statehood, and the national demarcation of legal and civil rights. ${ }^{38}$ But feminist criticism has shown that international relations (especially in their realist or neo-realist geo-political and geo-economic versions) rest on a view of the state and inter-state relations infused with dominant masculinities. ${ }^{39}$ I have already commented on military-police organization. The nation-state also tends to be strongly gendered. Indeed, ' $[\mathrm{t}] \mathrm{he}$ control of territory (by each state) is entwined with a definable gender contract that is a result of social struggle and is linked to a wider gender order in society'. ${ }^{40}$ The sovereign state functions as a 'power container' that institutionalizes gender and gender relations as well as classes and class compromises in three ways: its construction and consolidation of particular masculinities and femininities; its role in defining and monitoring the boundaries between different masculinities and femininities, classifying and punishing 'deviant' conduct; and selecting only some identities as the basis for recruiting individuals as state managers, representatives, or

\footnotetext{
${ }^{36}$ For a feminist critique of Elias's arguments on the origins of civilization in social pacification, see: Veronika Bennholdt-Thomsen, 'Zivilisation, moderner Staat und Gewalt', Beiträge zur feministischen Theorie und Praxis no.13, 1985, pp. 23-35.

37 Institutionalized racism and nationalism are also central to the organization of police-military functions.

${ }^{38}$ Andreas Behnke, 'Citizenship, nationhood and the production of political space', Citizenship Studies vol. 1 , no. 2 , 1997, pp. 243-65.

${ }^{39}$ For example, see: Cynthia Enloe, Bananas, Beaches, and Bases (London: Routledge, 1989); Rebecca Grant and Kathleen Newland, eds., Gender and International Relations (Milton Keynes: Open University Press, 1991); Birgit Locher-Dodge, 'Internationale Politik: geschlechtsneutrale Paradigmen?' in Eva Kreisky and Birgit Sauer, eds., Geschlechterverhältnisse im Kontext politischer Transformation (Opladen: Westdeutscher Verlag, 1997), pp. 425-49; V. Spike Peterson, ed., Gendered States (Boulder: Lynne Rienner, 1996); Jan Pettman, Worlding Women (London: Routledge, 1996); and Christine Sylvester, Feminist Theory and International Relations in a Postmodern Era (Cambridge: Cambridge University Press, 1994).

${ }^{40}$ Altha J. Cravey, 'Engendering the Latin American state', Progress in Human Geography vol. 22, no. 4, 1998, p. 538 .
} 
dialogue partners. ${ }^{41}$ Similar points hold for citizenship rights, which are also far more differentiated de jure and/or de facto than the liberal rhetoric of universal citizenship rights suggest. ${ }^{42}$

Globalization, cyberspace, and the spread of universal human rights now challenge these associations. Although human rights tend to generalize liberal assumptions of (western male) citizenship so that they are limited in intent and practice to men, they can serve as important strategic resources in gender and/or sexual preference struggles. ${ }^{43}$ They may also underpin transnational movements based on solidarity in difference, a particularization of rights, and a differentiated universalism; ${ }^{44}$ and, linked to citizenship, they can provide the basis for multi-tiered and pluralist struggles amenable to the pursuit of a broad spectrum of feminist concerns. ${ }^{45}$

Much has been written on women and the Rechtsstaat. Its rise did not immediately or directly challenge patriarchal forms of property in general as opposed to particular pre-capitalist instantiations thereof. Nor did it challenge the sexual contract implicit in the family as an organizational form. Moreover, even where formal equality was instituted in the public sphere, it co-existed with substantive inequalities. These issues can be explored in terms of three aspects of citizenship: (a) the 'isolation effect' and its implications for political struggles; (b) the relationship between the 'sexual contract' and social contract; and (c) the role of gender relations in reproducing the nation during the period of national states and in a possible future post-national era.

First, the grounding of political representation in individualized forms of national citizenship associated with the abstract individual rather than class position creates an 'isolation effect'. ${ }^{46}$ This encourages the organization of political space(s) around issues of formal equality, negotiated difference, or contested identities. In addition, macro-politics tends to take the form of hegemonic struggles to define the 'nationalpopular' interest in a sovereign state. ${ }^{47}$ Second, even if citizenship is formally genderneutral under universal suffrage (a right typically conceded quite late during modern state formation), it is historically and substantively based on a model of male citizenship. ${ }^{48}$ The reasons for this include stereotypical contrasts between male rationality and female emotion, men's military and fiscal duties as opposed to women's reproductive duties, and the perceived (male?) need to preserve domestic peace in the patriarchal family by depoliticizing gender relations. ${ }^{49}$ Unsurprisingly,

\footnotetext{
${ }^{41}$ Sarah A. Radcliffe, "“People have to rise up - like the great women fighters": the state and peasant women in Peru', in idem and Sallie Westwood, eds., Viva! Women and Popular Protest in Latin America (London: Routledge, 1993), p. 201.

${ }^{42}$ For a good survey of feminist criticisms and an original discussion, see Ruth Lister, Citizenship: Feminist Perspectives (New York: New York University Press, 1997).

${ }^{43}$ S.M. Okin, Women in Western Political Thought (Princeton: Princeton University Press, 1979); S. Reynolds, ed., Women, State, and Revolution: Essays on Power and Gender in Europe since 1789 (Brighton: Harvester, 1986).

${ }^{44}$ Ruth Lister, 'Dialectics of citizenship', Hypatia vol. 12, no. 4, 1996, p.11.

${ }^{45}$ Kate Nash, Universal Difference: Feminism and the Liberal Undecidability of Women. (Basingstoke: Macmillan, 1998).

${ }^{46}$ Nicos Poulantzas, Political Power and Social Classes (London: New Left Books, 1973).

${ }^{47}$ Antonio Gramsci, Selections from the Prison Notebooks (London: Lawrence and Wishart, 1971).

${ }^{48}$ Genevieve Lloyd, The Man of Reason: 'Male' and 'Female' in Western Philosophy (Minneapolis: University of Minnesota Press, 1984).

${ }^{49}$ On the third reason, see Carole Pateman, The Sexual Contract (Cambridge: Polity, 1988); and MacInnes, Masculinity.
} 
then, contradictions arose between the abstract right to citizenship and gendered particularities. The resulting conflicts have led to an uneven development and expansion of rights as well as to corresponding changes in the state. ${ }^{50}$ The development of human rights in three successive waves or generations (negative liberal individualist freedoms, positive rights based on state intervention, and, third, solidarity rights) has not addressed the specifically patriarchal bases of women's oppression. This is reflected in the fact that the Convention on the Elimination of all Forms of Discrimination against Women (1979) is the UN convention that has been ratified with the largest number of reservations by the largest number of signatory states. $^{51}$ This reflects the complexities of contemporary feminism. For other feminists have criticized human rights discourse and practices not for their disregard of the specificities of women's oppression but for their cultural blindness - for imposing a universalizing approach to women's rights without regard to legitimate cultural differences. ${ }^{52}$ Moreover, as Fraser notes in her critique of third-wave feminism, neither universalism nor multi-culturalism provides a basis for distinguishing just, democratic, and emancipatory identity claims from unjust, anti-democratic, oppressive identity claims. ${ }^{53}$

Third, the national state has taken three main forms: Volksnation, Kulturnation, and Staatsnation. Gender is crucial in the first form because membership of the 'imagined community' of the nation derives from descent and is inherited through the family. This gives women a key role as maternal 'bearers' of the nation but also leads to stricter control over their reproductive role in the 'national' interest. ${ }^{54}$ Membership of a Kulturnation depends more on acculturation or assimilation. Women still have a key role as socializers, however, along with state and non-state ideological apparatuses. ${ }^{55}$ The Staatsnation is yet more open because inclusion depends on loyalty to the constitution and patriotism. The decomposition of each of these forms of national state is putting a general strain on the role of gender in their reproduction. At the same time it creates opportunities to rethink what it might mean to belong to a state in a post-national era when the ethnic and/or cultural bases of nationality are being dissolved as it appears that societies are becoming more multi-ethnic or 'melting pot', have become more multicultural or fragmented, or have become playgrounds for 'hybridic' post-modern identities. These trends undermine the status of women as 'bearers' of the nation and/or national identity and have opened political spaces to redefine citizenship, to multiply the spheres of legitimate political action both within and across national borders, and to develop multiple political loyalties or even cosmopolitan patriotism. ${ }^{56}$

\footnotetext{
50 Antje Wiener, 'StaatsbürgerInnenschaft im Kontext: Staatsangerhörigkeit und Zugehörigkeit', in Teresa Kulawik and Birgit Sauer, eds., Der halbierte Staat. Grundlagen feministischer Politikwissenschaft (Frankfurt/M: Campus Verlag, 1996), pp. 112-16.

${ }^{51}$ Stanlie M. James, 'Challenging patriarchal privilege through the development of international human rights’, Women's Studies International Forum vol. 17, no. 6, 1994, pp. 568-69.

${ }^{52}$ Eva Brems, 'Enemies or allies? Feminism and cultural relativism as dissident voices in human rights discourse', Human Rights Quarterly no. 19, 1997, pp. 149-50.

53 Fraser, 'Equality', pp. 103-4

${ }^{54}$ Nira Yuval-Davis, Gender and Nation (London: Sage, 1996).

${ }^{55}$ Martial rape can be used as a weapon against ethnic and cultural nations, destroying families and cultures.

${ }^{56}$ Jürgen Habermas, 'Citizenship and national identity: some reflections on the future of Europe', Praxis International vol. 2, no. 1, 1992, pp. 1-19; David Held, 'Democracy: from city states to a cosmopolitan order', Political Studies vol. 40, Special Issue, 1992, pp. 10-39; Wiener, 'StaatsbürgerInnenschaft'; Nash, Difference.
} 


\section{Strategic Selectivity and Strategic Action}

To explore further the state's form-determined strategic selectivity we must move to more concrete and complex levels of analysis. There is now a vast historical and/or comparative literature on the gendering of particular state formations, welfare regimes, and policy domains; the specificities of different feminist movements and currents, successive 'waves' of feminism, and the impact of lesbian, gay, and 'queer' struggles; the intersection of different types of struggle (class, gender, ethnic, generational, anti-imperial, third-world, post-colonial, post-socialist, etc); and different strategies, alliances, tactics, spatial and temporal horizons. Rather than reviewing all these studies, I will highlight some basic strategic dimensions of the state and political system.

\section{Political representation}

Forms of political representation are gender-biased. This is seen in legal definitions of individual citizenship, the mode of separation between the private and public spheres, the nature of the public sphere as a site of political deliberation, the relative importance of territorial and functional bases of political decision-making, individual and/or collective mechanisms of decision-making, and electoral rules such as proportional representation, majority voting, or simple plurality. Substantive variations in representation also matter. These include the social, ideological, and organizational aspects of political representation in the party system, interest groups, or social movements; varying capacities to access the public sphere and mass media; and differential capacities to access or intervene in the state.

The private-public separation also has specific effects. These are stronger, of course, the more this distinction is fetishized. Not is there a tendency for women to be confined to the private sphere; but the public sphere also favours appeals to rational and 'universal' rather than emotional and/or 'particular' interests. ${ }^{57}$ This is said to marginalize women's issues and interests. First- and second-wave feminisms responded with attempts to move into the public sphere and to emphasize either the value of 'maternal' or other feminine values to political life and/or women's capacity to engage in rational argument. Moreover, where women do enter the formal public sphere, advocates of women's 'natural' roles find this easier to accomplish than lesbian, gay, or 'queer' movements or advocates of other types of role. It is also easier for liberal feminists to access the public sphere than radical, socialist, or anarchist feminists. Focusing on the public sphere also leads to neglect of women's political activities outside the formal party and parliamentary political arenas - such as informal neighbourhood politics, local social movements, or client-state negotiations in the welfare regimes. ${ }^{58}$ This does not mean, of course, that the private-public distinction should be rejected as opposed to being demystified; that it is useless to

\footnotetext{
${ }^{57}$ Jean Cohen, Andrew Arato, eds., Civil Society and Social Theory (Cambridge, MA: MIT Press, 1992); Craig Calhoun, ed., Habermas and the Public Sphere (Cambridge, MA: MIT Press, 1994); Joan B. Landes, ed., Feminism: the Public and the Private (Oxford: Oxford University Press, 1998); Sieglinde Katharina Rosenberger, 'Privatheit und Politik', in Eva Kreisky and Birgit Sauer (eds), eschlechtverhältnisse, pp. 120-136.

${ }^{58}$ Julia S. O'Connor, 'Gender, class and citizenship in the comparative analysis of welfare state regimes', British Journal of Sociology vol. 44, no. 4, 1993, p. 506.
} 
engage in struggles to redraw the distinction or exploit its ambiguities. Nor does it mean that certain masculine forms of politics are irrational; that new networking forms of politics or governance may well be challenging the apparent clarity of the private-public distinction; or even that ideas and strategies grounded in the third-wave feminist concept of cyborg politics might not better correspond to women's experience of the private-public distinction and exploit more effectively the energy of 'borderlands'. 59

Regarding territorial representation, the more local the level of political organization, the easier is women's access to political power. Different biases occur in corporatist or functional forms of representation. Estate-like corporatism is more patriarchal than social democratic forms. Even the latter privilege the male-dominated world of business organizations, trade unions, and other producer interests at the expense of those without gainful employment and consumers. Unsurprisingly, the greater the political influence of such corporatist arrangements compared to parliamentary institutions, the greater is the social and economic gap between men and women and the harder it is to realize gender equality policies. ${ }^{60}$ Analogous criticisms, albeit identifying different modes of selectivity, have been leveled against new forms of participatory governance on the grounds that they privilege only certain types of participant, participation, expertise, and everyday experience. ${ }^{61}$

The marginalization of women candidates and women's issues as well as the downplaying of the private sphere have long shaped electoral politics, especially in majoritarian rather than proportional representation systems. The former encourage catchall parties that are less inclined to allow serious space for feminist concerns. But women can have more impact on formal politics where compacts between feminists and a given party (or parties) allows women's policy activists to access state institutions. $^{62}$ Types of issue also shape women's unity and influence. Thus they are strongest for issues around sexual politics (abortion, violence against women, incest, pornography) or daily life (work hours, childcare, pay and employment equity). ${ }^{63}$ Social movements may take up women's issues but have less privileged access to the state or face the dilemmas of being in and against the state. ${ }^{64}$ Moreover, as the suffrage expanded to include workers and women, key areas of political power were

\footnotetext{
${ }^{59}$ See Donna Haraway, Simians, Cyborgs and Women: the Reinvention of Nature. (London: Routledge, 1991).

60 Gerda Neyer, 'Korporatismus und Verbände. Garanten für die Stabilität eines sexistischen Systems', in Kulawik and Sauer, eds., Der halbierte Staat, p. 84. On the double gender marginalization produced by the parliamentary Fraktionsstaat and corporatism in Germany, see Brigitte Young, 'The German state and feminist politics: a double gender marginalization', Social Politics vol. 3, no. 2-3, 1996, pp. 159-84.

${ }^{61}$ For a good overview, see Barbara Holland-Cunz, 'Perspektiven der Verhandlungsdemokratie Governance-Prozesse aus frauenpolitischer Sicht'. In Claus Leggewie and Richard Münch, eds, Politik im 21 Jahrhundert (Frankfurt: Suhrkamp, 2001), pp. 281-296.

${ }^{62}$ Monica Threlfall, 'State feminism or party feminism?' in European Journal of Women's Studies vol. 5 , no. 1,1998 , p. 71.

${ }^{63}$ O'Connor, 'Gender', p. 506.

${ }^{64}$ On femocracy see: Suzanne Franzway, Dianne Court, Robert W. Connell, Staking a Claim: Feminism, Bureaucracy, and the State (Cambridge: Polity, 1989); D. M. Stetson and A. Mazur, eds., Comparative State Feminisms. (London: Sage Publications, 1995);Threlfall, 'State feminism'; Sophie Watson, 'Femocratic feminisms', in Mike Savage and Ann Witz, eds., Gender and Bureaucracy (Oxford: Blackwell, 1992), pp. 186-204.
} 
moved from elected legislatures to the executive, quangos, and functional representation. ${ }^{65}$

\section{The architecture of the state}

Gender effects also occur in the formal and material distribution of powers in and/or among parts of the state apparatus. As well as the relative separation of executive, legislative, and judicial powers, we find a hierarchy of departments in the state system and a relative distribution of powers across its different tiers. It is well known that, the closer a department is to the core of the repressive state apparatus (military, police, security, foreign policy, and treasury), the fewer women are present. The same holds for higher tiers of government. These trends are related because the state's 'softer' functions tend to be located at the local level. We also need to consider the informal 'parallel power networks' that help to unify formal hierarchies. Some feminist research indicates that these parallel power networks are often more male-dominated than formal bureaucratic bodies. ${ }^{66}$ For such networks tend to display the atmosphere and mores of a men's club. Some gay theorists also suggest that the military is more heterosexist than civilian state apparatuses. ${ }^{67}$ Overall, one must examine how the state's precarious unity is created and how this, in turn, creates various gender selectivities.

State feminism provides an interesting test case here as it promotes policy-making bodies led by women and/or dedicated to women's issues. These bodies are a response to pressures from below as well as an attempt to co-opt feminism. They can empower women to pursue their own interests but can also generate public forms of patriarchy whereby women come to depend collectively on 'father state' rather than individually on fathers, husbands, or son. ${ }^{68}$ Threlfall identifies several forms of state feminism - ranging from social democratic femocracies to patriarchal-authoritarian forms of national mobilization - with a correspondingly wide range of effects. ${ }^{69}$

A broad range of dilemmas and contradictions also affect women's struggles in and against the state. ${ }^{70}$

\section{The primary 'media' of state intervention and forms of intervention}

\footnotetext{
${ }^{65}$ Helga M. Hernes, Welfare State and Woman Power: Essays in State Feminism (Oslo: Norwegian University Press, 1987); Birte Siim, 'Welfare state, gender politics and equality policies: women's citizenship in the Scandinavian welfare states', in Kathleen B. Jones and Anna G. Jónasdóttir, eds., The Political Interests of Gender (London: Sage, 1991), pp. 160-86; Drude Dahlerup, 'Learning to live with the state: state, market, and civil society', Women's Studies International Forum vol. 17, no. 2-3, 1994, pp. 117-27.

${ }^{66}$ Katherine Ferguson, The Feminist Case against Bureaucracy (Philadelphia: Temple University Press, 1984).

${ }^{67}$ David F. Greenberg and Marcia H. Bystryn, 'Capitalism, bureaucracy, and male homosexuality', in Steven Seidman, ed., Queer Theory/Sociology (Oxford: Blackwell, 1996), pp. 83-110.

${ }^{68}$ Mervat Hatem, 'Economic and political liberalisation in Egypt and the demise of state feminism', International Journal of Middle East Studies no. 24, 1992, pp. 231-51; Walby, Patriarchy.

${ }^{69}$ Threlfall, 'State feminism'.

${ }^{70}$ See Stetson and Mazur, eds., State Feminisms; Monica Threlfall, ed., Mapping the Women's Movement: Feminist Politics and Social Transformation in the North (London: Verso, 1996); Susan Findlay, 'Feminist struggles with the Canadian state: 1966-1988, Resources for Feminist Research vol. 17 , no. 3,1988 , pp. 5-9.
} 
The state deploys various means of intervention, each with its own forms of gender bias: here I consider force, law, money, and knowledge. The masculine and military values linked to the state's monopoly of force were noted above. The formality of positive law tends to abstract not only from substantive class differences but also from those based on gender. Moreover, even where the latter are recognized (if not also, indeed, actually constituted) in some branches of the law, their recognition may serve to create and/or re-impose forms of public and private patriarchy. ${ }^{71}$ Thus law may offer women special treatment by virtue of their gender (e.g., maternalist or natalist policies) or protect them only if they accept their subordinate status in the private sphere. Law also gives the state rights to intervene in women's lives - especially if they present themselves and/or are presented as victims. ${ }^{72}$ More generally, in accepting law's terms in order to challenge law, feminism always concedes too much' ${ }^{73}$ For this concedes the hegemony of law and its androcentric standards, fetishizes legal categories and methods, and marginalizes non-legal knowledge and experiences as well as extra-legal strategies. ${ }^{74}$ The shift from formal procedural to reflexive law might make a difference here by opening legislation and adjudication to debate over substantive inequalities. There is some progress in this regard through the work of feminist legal theorists as well as of legal practitioners on behalf of their clients. $^{75}$

Money is the basis of formally rational calculation on capitalist markets and in ideal market conditions such calculation would ignore differences that do not affect profitand-loss or purchasing power. ${ }^{76}$ In the real world, of course, this disadvantages most women, who are typically poorer than men. Nonetheless the emergence of the 'pink pound' or pornography targeted at women rather than men suggests that markets will exploit profitable new niches. The state reproduces the same utilitarian calculus whenever it adopts cost-benefit analysis (with women's costs-benefits having a lower value than those of men) or confirms differentials rooted in the division of labour or differences in income or wealth. This is especially evident in the ways in which the state reproduces the relation between capital and wage labour - including a politics of workers-men; ${ }^{77}$ in the gender-specific impact of structural adjustment policies; ${ }^{78}$ and in the sphere of welfare policies (e.g., pensions or social security benefits). Knowledge has become more and more important for the state's operations. However, not only are there frequently substantive biases in bodies of knowledge (linked as they are to power), but there is also a sense in which the very formal, systematic, rational and scientized form of knowledge embodies masculine perspectives. In addition, insofar as statecraft is intrinsically connected to the concepts of sovereignty,

\footnotetext{
${ }^{71}$ Catherine MacKinnon, Toward a Feminist Theory of the State (Cambridge, MA: Harvard University Press, 1989).

72 Wendy Brown, States of Injury: Power and Freedom in Late Modernity (Princeton: Princeton University Press, 1995).

${ }^{73}$ Carol Smart, Feminism and the Power of Law (London: Routledge, 1989), p. 5.

${ }^{74}$ Ibid.

${ }^{75}$ See Sondra Farganis, Situating Feminism: From Thought to Action, (London: Sage, 1997).

${ }^{76}$ On efforts to re-entangle money into gendered social relations, see Viviana A. Zelizer, 'The proliferation of social currencies', in Michel Callon, ed., The Laws of the Markets. Oxford: Blackwell, 1998), pp. 58-68.

${ }^{77}$ Teresa Kulawik (1996) 'Modern bis maternalistisch: Theorien des Wohlfahrtsstaates', in Kulawik and Sauer, eds., Der halbierte Staat, p. 52.

${ }^{78}$ M. Patricia Connelly, 'Gender matters: global restructuring and adjustment', Social Politics vol. 3, no. 1,1996, pp. $12-31$
} 
Realpolitik and hegemonic masculinity, then political knowledge reproduces gender differences. $^{79}$

These media can be combined to support specific forms of state intervention. Welfare regimes illustrate this well because they are located at the intersection of state, market, and family-gender relations and thereby embody many of the contradictions between women and the state. Maintaining the traditional family was an important object as well as presumption in the initial design of welfare states; for the state organized welfare "not around a biological core, but a state-sanctioned, heterosexual marriage that confers legitimacy not only on the family structure itself but on children born into it'. ${ }^{80}$ Yet variations occur in welfare regimes not only concerning decommodification (reducing workers' dependence on the labour market) but also regarding a person's insulation from involuntary economic dependence on other family members and/or state agencies. ${ }^{81}$ In the latter respect women rely disproportionately on dependence-enhancing income and/or means-tested benefits rather than on universal citizenship rights. Thus they can be regarded as second-class citizens or welfare claimants.

The women-friendliness of welfare regimes varies greatly. ${ }^{82}$ Skocpol notes how a maternalist welfare regime developed at the states level in the USA ahead of Europe's more paternalist, male breadwinner model at the national level. ${ }^{83}$ Yet, as Kulawik ${ }^{84}$ notes, although the maternalist regime was based on women's political mobilization at decentralized states level, this actually served to ensure the secondary status of American welfare compared to rights-based European regimes. There are variations within Europe too. The more guild-like corporatist welfare regimes in Austria and Switzerland are less women-friendly than social democratic welfare regimes in Scandinavia. ${ }^{85}$ Even the latter, whilst more advanced in integrating women into the labour market, de-familializing care work, and enabling women to share in welfare policy making, have seen little real increase in women's social and political power or development of an autonomous feminist collective identity. ${ }^{86}$

\section{Gender specific inequalities in the social bases of state power}

The social bases of state power are linked to hegemonic masculinities and femininities as well as to the material foundations of state power. These affect the formation of a relatively stable social compromise and loyalty to the state form or regime. They also shape the compatibility between the demands of political legitimacy (electoral success) and those of real politics (including both accumulation and geopolitics). These features must be elaborated for individual state forms, taking account not only

\footnotetext{
${ }^{79}$ See, for example, Grant and Newland, eds., Gender.

${ }^{80}$ Collins, 'It's all in the family', p. 63.

${ }^{81}$ O'Connor, 'Gender', p. 512.

${ }^{82}$ See Julia S. O'Connor, 'From women in the welfare state to gendering welfare state regimes', Current Sociology vol. 44, no. 1, 1996, pp. 1-124.

${ }^{83}$ Theda Skocpol, Protecting Soldiers and Mothers: the Political Origins of Social Policy in the United States (Cambridge: Cambridge University Press, 1992).

${ }^{84}$ Kulawik, 'Modern'.

${ }^{85}$ Gerda Neyer, 'Korporatismus und Verbände: Garanten für die Stabilität eines sexistischen Systems', in Kulawik and Sauer, eds. Der halbierte Staat, pp. 82-104.

${ }^{86}$ Kulawik, 'Modern', p. 61.
} 
of institutionalized class compromises but also of specific forms of gender contract. Duncan has defined the latter as 'the balance of power that is worked out between men and women in particular places, ${ }^{87}$. A key question here is whether the state's social basis is also the principal beneficiary of its exercise of power. Patriarchal, maternalist, and nationalist discourses all have key mystificatory roles in this regard. For these shape the identities and interests that provide the material and symbolic substratum for gender contracts, for the recruitment and stabilization of supporting classes, for the stakes to be negotiated in temporary alliances, and for the roles of different sex/gender categories in private and public life. Together with material structures of power, they also shape the forms of social inclusion and exclusion. In all cases there are clear links to the structural aspects of the gendered selectivity of the state.

\section{Hegemonic projects related to the state}

Hegemonic projects define the nature and purposes of the state and are typically gender-biased. This is a vast field of research and one recent example must suffice. Thus Brodie explores this in the successive meso-narratives that have structured the state as a form of political domination. ${ }^{88}$ She argues that liberal citizenship was oriented to universalism over particularism - with women regarded as particularist and unable to transcend this to achieve universalism. Next, the 'laissez-faire state was extremely active in ensuring the autonomy of the market and the domestic sphere and the power relations exercised within them. It pronounced its 'others' (sc. market, home) as apolitical and self-regulating and, thus, not subject to public intervention'. Later, the Keynesian welfare state 'realized a radical expansion of the public through direct intervention in the economy, and by subjecting the family, and other aspects of private life, to new forms of state scrutiny and assistance. [...] The family wage and the dependent homemaker/mother were cultural forms that were cultivated by the welfare state'. This state form advances the claims of white middle class. Finally, the neo-liberal meso-narrative emphasizes performativity. In its fatalism in the face of market forces, its emphasis on the positive effects of globalization, and its genderneutral approach to restructuring, it can be regarded as a phallocentric discourse. ${ }^{89}$

\section{Conclusions}

Paraphrasing Marx's comments on production in general, we can say that, although there is no 'patriarchy in general', particular forms of patriarchy do exist. ${ }^{90}$ Indeed they are institutionalized in, and reproduced by, the modern state. But we should distinguish the gender-conditioned aspects of the state, its substantively gendered

\footnotetext{
${ }^{87}$ Simon Duncan, 'Theorising differences in patriarchy', Environment and Planning A no.26, 1994, p.1186. See Robert W. Connell, 'New directions in gender theory, masculinity research, and gender politics', Ethnos vol. 6, no. 3-4, 1996, pp. 152-76; and Nancy A. Naples, "The "New Consensus" on the Gendered "Social Contract": The 1987-1988 U.S. Congressional hearings on welfare reform', Signs vol. 22, no. 4, 1997, pp. 907-45.

${ }^{88}$ Janine Brodie, 'Meso-discourses, state forms and the gendering of liberal-democratic citizenship', Citizenship Studies vol. 1, no. 2, pp. 222-42.

${ }^{89}$ Ibid., pp. 230, 232, 233, 238.

${ }^{90}$ Cf. Karl Marx, 'Introduction', in idem, Grundrisse: Foundations of the Critique of Political Economy (Rough Draft) (Harmondsworth: Penguin, 1973), pp. 81-111, at p. 101.
} 
nature, and its gender-relevance beyond the state. And we should explore each aspect, not in terms of fetishized, naturalized sex or gender distinctions, but in terms of the multifarious forms in which sex and/or gender are construed, constructed, selected, and reproduced. A critical realist, strategic-relational approach is especially appropriate here because it promotes a retroductive analysis of the underlying (real) mechanisms that generate certain gender selectivities within the state apparatus and its environing political system and the patterns of conduct that either serve to realize, to redirect, to block, or to transform these selectivities in specific contexts, over specific spatial and temporal horizons, and so forth.

First, gender regimes condition the state insofar as they shape political opportunities and constraints. Just as capital and male-dominated unions sometimes find it 'profitable' to exploit existing gender differences to segment the labour force structurally and divide it organizationally, so state managers and politicians may exploit gender divisions by fashioning political appeals, building social bases, etc., on gender lines. Moreover, even when women win formal equality as citizens, gender regimes may prevent its realization. For example, while state action may compensate for private patriarchy or the gendered division of labour, it may also create forms of public patriarchy that bind women to men via the welfare state. ${ }^{91}$ In short, insofar as the modern state's operations are gender-conditioned (because they are structurally coupled to and co-evolve with patriarchal relations), its own gender-neutrality must be limited. Second, insofar as the modern state reproduces patriarchy and patriarchal ideology in its own organization, it is itself gendered. This occurs through a myriad contingent practices and, following Butler ${ }^{92}$ and many others, one could say that states perform gender. And, third, state activities are gender-relevant insofar as they reproduce institutionalized contexts and discourses in which patriarchy appears natural - for example, the role of social policy in reproducing the patriarchal family or gender specific differences on the labour market.

Nonetheless, since the modern's state patriarchal features derive from a contingent coevolution with patriarchal relations beyond the state, feminist strategies that make it 'bad for government' to pursue patriarchy-friendly policies may be effective. This has occurred in the last three decades in advanced capitalist democracies. There is still far to go, however; and many achievements may prove reversible - as neo-liberalism and neo-conservatism demonstrate in their different ways. Yet the lines of conflict have become harder to decipher due to proliferation of femininities/masculinities and/or growing recognition of the problems of heteronormativity.

\footnotetext{
${ }^{91}$ Helga Hernes, 'Women and the welfare state: the transition from private to public dependence', in Harriet Holter, ed. Patriarchy in a Welfare Society (Oslo: Universitetsforlaget, 1984), pp. 20-46; Kulawik, 'Modern'; Walby, Patriarchy. For the counter-argument that women can use the welfare state to advance their interests, see Hernes, 'Women'.

92 Judith Butler, Gender Trouble: Feminism and the Subversion of Identity (New York: Routledge, 1990).
} 
The implications of the contingently necessary nature of the state's selectivities are complex. It is far easier to note what they exclude than work out what they entail. A critical realist, strategic-relational approach to this question excludes naturalizing, universalizing essentialisms based on simple oppositions such as male/female and masculine/feminine. It does not exclude a weak, historically contingent essentialism in the sense of intrinsic properties or structures at the level of the real that are only tendentially actualized and are themselves only tendentially reproduced (i.e., these properties are, as noted earlier, 'doubly tendential' rather than natural and universal). Thus the state's structurally inscribed strategic selectivities do not operate in the sort of binary fashion that would justify its description as the 'patriarch general' or as necessarily heteronormative. Strategic selectivities are real causal mechanisms that operate tendentially, are subject to counter-tendencies, and are actualized through specific social practices and actions. But even those who reject strong essentialist claims sometimes deploy 'strategic essentialism' and/or 'asymmetrical antiessentialism' in political struggles. In this regard, whereas strategic essentialism involves a self-conscious, provisional, and even ironical, deployment of essentialist arguments for strategic purposes in specific contexts, asymmetrical anti-essentialism only tolerates such arguments when voiced by subaltern groups to contest their stereotypical 'otherization', to resist their inclusion within Enlightenment time and space, and to assert the authenticity of their cultures. ${ }^{93}$ But, however self-conscious and self-limiting, both strategies are problematic insofar as they privilege an identitarian approach to political mobilization, i.e., an essentializing politics of identity. This reifies boundaries between groups and, by homogenizing and collapsing individual into collective identities, also tends to be undemocratic within groups. ${ }^{94}$ At most they can provide the basis for political mobilization based on an aggregative, serialized but still essentializing concept of identity that ignores 'the complex interweaving and continual re-embedding of identities and subjectivities'. ${ }^{95}$ Such effects are opposed in the emerging third-wave feminist emphasis on intersectionality (and the parallel critique of essentialism from queer theorists) and on the benefits of dialogue between different standpoints or positions (cf. feminist standpoint epistemologies).

Thus the emphasis should be on possible, negotiable, and partial collaborations between feminists and other social categories around specific projects; and on how different projects can be unified into broader, more general struggles. This approach has been described as 'transversal politics' and, according to Yuval-Davis, it stops 'where the proposed aims of the struggle are aimed at conserving or promoting unequal relations of power, and where essentialized notions of identity and difference naturalize forms of social, political and economic exclusion'. ${ }^{96}$ This approach fits feminist ideas about contextual ethics; and the need for situated, local understanding

\footnotetext{
93 On strategic essentialism, see Gayatri C. Spivak, 'Can the subaltern speak?' in Lawrence Grossberg and Cary Nelson, eds., Marxism and the Interpretation of Culture (Urbana: University of Illinois Press), 271-316; and, critically, Duggan, 'Queering', and Ngai-ling Sum, 'From politics of identity to politics of complexity: a possible research agenda for feminist politics/movements across time and space', in Sara Ahmed et al., eds., Transformations: Thinking through Feminism (London: Routledge, 2000), pp. 131-44. On asymmetrical anti-essentialism, see Annie Bunting, 'Theorizing women's cultural diversity in feminist international human rights strategies', Journal of Law and Society vol. 20, no. 1, 1993, pp. 6-22.

${ }_{94}$ Nira Yuval-Davis, “What is “transversal politics"?', Soundings no. 12, 1999, p. 94.

${ }^{95}$ Sum, 'Politics of identity'.

${ }^{96}$ Yuval-Davis, “"Transversal”, p. 97.
} 
rather than universal, codified knowledge. In adopting this approach, one moves beyond the old feminist question - 'can we achieve feminist goals directly through the agencies of the state?' - to a new question: 'what kind of state should we be attempting to construct?" ${ }^{97}$ A provisional answer is that this should be a state form that institutionalizes a mode of political engagement that sustains conflict in politically productive ways. ${ }^{98}$ This works against both universalist feminisms and against multi-cultural rainbow coalitions that operate in a mechanically aggregative manner. Thus we need 'to find a way to combine the struggle for an anti-essentialist multiculturalism with the struggle for social inequality and democracy ${ }^{99}$. But this in turn requires attention to the politics of complexity as well as the politics of identity. ${ }^{100}$ In short, it requires attention to the complex strategic-relational interaction between state structures and individual and collective identities and interests in specific conjunctures. ${ }^{101}$ The preceding remarks provide some preliminary theoretical indications on how to proceed in this regard but they cannot substitute for practical interventions to test the nature and limits of the state's selectivities and the merits of different strategies.

\footnotetext{
${ }^{97}$ Ann Curthoys, 'Feminism, citizenship and national identity’, Feminist Review 44, 1993, p. 36.

98 Judith Butler, 'Merely cultural', Social Text no. 52-53, 1997, p. 269.

${ }^{99}$ Fraser, 'Equality', p. 108.

${ }^{100}$ Sum, 'Politics of identity'.

101 See also Alex Demirovic and Katharina Pühl, 'Identitätspolitik und die Transformation von Staatlichkeit: Geschlechter-verhältnisse und Staat als komplexe materielle Relation', in Kreisky and Sauer, eds. Geschlechtverhältnisse, pp. 000-00.
} 